\title{
Limits on quality of life in communication after total laryngectomy
}

\author{
Adriana Di Donato Chaves', Leandro de Araújo Pernambuco², Patrícia Maria Mendes Balata ${ }^{3}$, Veridiana da Silva Santos 4 , \\ Leilane Maria de Lima ${ }^{5}$, Síntia Ribeiro de Souza ${ }^{6}$, Hilton Justino da Silva ${ }^{7}$.
}

1) Doctor in course in Linguistics. Federal University of Paraíba - (Assistant Professor in Speech Therapy).

2) Doctor in course in Public Health Federal University of Rio Grande do Norte - (Assistant Professor in Speech Therapy).

3) Doctor in course in Neuropsychiatry and Behavioral Sciences Federal University of Pernambuco - (Speech Therapy).

4) Master in Biometrics -Federal Rural University of Pernambuco - (Assistant Professor in Statistics).

5) Speech Therapy. Federal University of Pernambuco - (Speech Therapy).

6) Specialized Center in Speech Therapy - Redentor College - (Speech Therapy)

7) $\mathrm{PhD}$ in Nutrition -. Federal University of Pernambuco - (Adjunct Professor 2).

Institution: Universidade Federal de Pernambuco.

Recife / PE - Brazil.

Mailing address: Adriana Di Donato - Universidade Federal de Pernambuco/ Departamento de Fonoaudiologia - Rua Arthur de Sá, s/n - Cidade Universitária - Recife / PE - Brazil - Zip code: 50740-520 - Telephone: (+55 81) 2126-8927 - E-mail: adrianadidonato1@gmail.com

MCT/CNPq/CT-Saúde/MS/SCTIE/DECIT nº 67/2009 - REBRATS

Article received in April 24, 2012. Article approved in August 10, 2012.

\section{SUMMARY}

Introduction: Among people affected by cancer, the impairment of quality of life of people affected by cancer can cause have devastating effects. The self-image of patients after post-laryngectomyzed patients may be find themselves compromised, affecting the quality of life in this population.

Objective: To characterize quality of life in related to communication in people who have undergone went total laryngectomy surgery.

Methods: This is an observational study, with a cross-sectional and descriptive series.

Design of series study. The sample were comprised 15 patients interviewed the period from January to February of 2011 . We used the Quality Protocol for Life Communication in Post-laryngectomy adapted from Bertocello (2004); which this questionnaire contains 55 questions. The protocol was organized from the nature of using responses classified as positive and negative aspects, proposals in with respect to five 5 communication domains: family relationships, social relationships, personal analysis; morphofunctional aspect, and use of writing. To promote and guarantee the autonomy of the respondents, was examiners made use of used assistive technology with the Visual Response Scale.

Results: The responses that total laryngectomy compromises the quality of life in communication amounted to 463 occurrences (65.7\%), and that who responses suggesting good quality of life were represented with amounted to 242 occurrences (34.3\%), from a total of 705 occurrencesresponses. From Among the five 5 Communication domains, four 4 had percentages of above $63 \%$ for occurrences of negative content for impact on communication. Appearance Morphofunctional appearance gave the had the highest percentage of negative content, amounting to $77.3 \%$ of cases.

Conclusions: The results showed important limitations of a personal and social nature due to poor communication with their peers. Thus, there is a need for multidisciplinary interventions that aim to minimize the entrapment of negative impact on these people communication among these patients.

Keywords: quality of life; laryngectomy; communication; protocols.

\section{INTRODUCTION}

For the year 2012, in Brazil, it is an expected 6,110 new cases of laryngeal cancer are expected, with an estimated risk of 6 cases per 100000 individuals. The Laryngeal cancer is the sixth most frequent in the Northeast region (4/100 000). ), seventh in the South region (9/100 000) and North regions (2/100 000), occupies the seventh position; eighth in the Southeast region (8/100 000), eighth, and ninth in the Midwest region (5/100 000), the ninth (1) position.

The Therapeutic procedures indicated for patients suffering from laryngeal cancer in advanced stages is the total laryngectomy. Despite his statement efforts to be very careful, that is, and operate only when it has there is a high degree of infiltration and involvement (stages III and IV) (2-4), changes in chewing, deglutition, breathing, and speech (5) presents serious complications as in the patient's life, particularly in interaction with their peers. The selfimage of laryngectomiyzed patients may be find themselves compromised, further affecting the quality of life in this population (6-7), and may also result in pain, postural changes, difficulty in performing daily tasks, and sleep disorders (2,8-12).

The Communication is put effected into the society through various codes used by men individuals to express their views ,and to represent things, beings, and ideas; 
and among them these codes, the most important is the language. Many authors describe the impact of communication and adaptation after laryngectomy in surviving patients with survival(13-17). The ability to communicate has a very strong association with improved quality of life (13-17). However, other studies do not have point to report the existence of a correlation between quality of life and speech (18).

While there is no consensus on the concept of quality of life, three 3 fundamental aspects related to its construct nature were obtained through the work of a group of scholars from different cultures. They are (1) subjectivity, (2) multidimensionality, and (3) presence of positive dimensions (e.g.: mobility) and negative (e.g.: pain). The development of these elements led to the definition of quality of life as " an individual's perception of their position in life in the context of (the) culture and value system in which they live and in relation to their goals, expectations, standards and concerns"," defined by the WHOQOL GROUP (19).

The impairment of quality of life of people affected by cancer can cause devastating damage to entire families., This is especially true when the head of the family who is the provider of the only source of income gets sick, being the provider of the only source of income, as well as when one 1 parent is affected by the disease and children come to exercise have to care activities of the family, failing to take live their lives within according to the standards expected for their age (1).

To this end, we applied the Protocol for the Evaluation of Communication Satisfaction of Patients after Total Laryngectomy adapted from Bertoncello (20) (Table 1), a validated instrument that measures the degree of satisfaction of the patient with his/her's communication after total laryngectomy, and presents objective questions that facilitate the participant's response.

In order to post scenario, Communication difficulties permeate family, professional, and social relationships of a family, professional and social, uniquely affecting uniquely the quality of life of these subject's patients (20). This article aims to evaluate the satisfaction of communication and its relationship to quality of life in patients after total laryngectomyzed.

\section{METHOD}

This is an observational study, with a cross-sectional descriptive. Design of series study. This study is part of the research entitled "'Quality of life and its relations with the use of diagnostic technologies in human communication disorders in rural workers who underwent total laryngectomy," ," Call MCT/CNPq/Health-CT/MS/ SCTIE/DECIT no. 67/2009 - REBRATS, with approval by the Ethics Committee in Research of Pernambuco Society for Fighting Cancer/Cancer Hospital of Pernambuco, $\mathrm{n}^{\circ}$. 67/2010.

We adopted the following profile of volunteers to participate in the study: (a) Inclusion criteria were as follows: an aged between 40 and 75 years; both sexes; who underwent surgery for total laryngectomy with or without neck dissection; at least 45 days; adjuvant radiotherapy; being serviced at the Speech Pathology (SEFON) Department of Head and Neck (DCCP) from the present hospital; and signature on the Instrument of Consent (TCLE).; (b) Exclusion criteria criteria were as follows: previous head and neck surgery; hold another type of laryngectomy, or tracheotomy prior to total laryngectomy; alternative route of feeding way prior to total laryngectomy or present at the time of application of the protocol, ; patients who underwent history of postoperative complications (pharyngocutaneous phystula, dehiscence, and tissue necrosis); previous frame of difficulty in understanding simple commands or neurological/neuromuscular/neurodegenerative disease, ; and individuals who refuse to participate on in the study.

Data were collected and applied on a chip containing participant personal data items relating name, age, gender (male/female), schooling, and occupational status functional (active and retired). On the basis of the schooling, topic the participants were organized into four 4 groups: (illiterate; 1 to 4 years of schooling; 5 to 8 years of schooling; and 9 to 11 years of schooling). Here goes for clarification regarding the adoption of the schooling classification criteria. From the Federal Resolution no. 4 of 07.13.2010 (21), which stablisheds the National General Curriculum Guidelines for Basic Education, and made 9 years of primary education it became compulsory primary education with nine years. However, we chose to keep the schooling calculations given on eight years of compulsory education, considering that the our research sample was composed of adults and elderly, who would have been schooled so when the previous regime statute still in force with eight years of schooling was still in force.

All patients were in had adapted of an esophageal speech process, since because the service of this hospital does not offer the traqueosophagic or electronic larynx prosthesis. The research population belonged to lowincome groups and generally therefore also has had no own spare resources for acquiring them prostheses on their own.

Subsequently, we applied the Protocol for the 
Table I. Functional assessment of communication with patients after total laryngectomy. Adapted from Bertoncello (2004).

\begin{tabular}{|c|c|c|c|c|c|c|c|}
\hline Issues & $\begin{array}{l}\text { Commu- } \\
\text { nication } \\
\text { domains }\end{array}$ & $\begin{array}{l}\text { Notat } \\
\text { all true } \\
\text { score } \\
\mathrm{n}(\%)\end{array}$ & $\begin{array}{c}\text { Somewhat } \\
\text { true } \\
\text { score } \\
\mathrm{n}(\%)\end{array}$ & $\begin{array}{l}\text { More } \\
\text { true } \\
\text { score } \\
\mathrm{n}(\%)\end{array}$ & $\begin{array}{l}\text { Very } \\
\text { true } \\
\text { score } \\
\mathrm{n}(\%)\end{array}$ & $\begin{array}{c}\text { Very much } \\
\text { true } \\
\text { score } \\
\mathrm{n}(\%)\end{array}$ & Total \\
\hline 1. Before surgery my way of speaking was easy to understand & d RS & $2(13.3 \%)$ & $3(20 \%)$ & I (6.7\%) & I (6.7\%) & $8(53.3 \%)$ & 15 \\
\hline 2. My way of speaking interferes with my work & RS & NA & NA & $2(13.3 \%)$ & NA & | (6.6\%) & 3 \\
\hline 3. My way of speaking interferes in the relationship with my family & y $R F$ & $3(20 \%)$ & I (6.7\%) & $3(20 \%)$ & $3(20 \%)$ & $5(33.3 \%)$ & 15 \\
\hline 4. My way of speaking interferes with the interaction with others & RS & $3(20 \%)$ & - & $4(26.7 \%)$ & $4(26.7 \%)$ & $4(26.7 \%)$ & 15 \\
\hline $\begin{array}{l}\text { 5. I stopped attending parties (social gatherings) because of } \\
\text { embarrassment caused by my manner of speaking }\end{array}$ & RS & $6(40 \%)$ & - & I (6.7\%) & I (6.7\%) & $7(46.7 \%)$ & 15 \\
\hline $\begin{array}{l}\text { 6. When I go out I choose less crowded streets to not find } \\
\text { known people }\end{array}$ & AP & $9(60 \%)$ & I (6.7\%) & - & - & $5(33.3 \%)$ & 15 \\
\hline $\begin{array}{l}\text { 7. My friends stopped coming to my house because of my } \\
\text { difficulty speaking }\end{array}$ & AP & $6(40 \%)$ & I (6.7\%) & $3(20 \%)$ & $2(13.3 \%)$ & $3(20 \%)$ & 15 \\
\hline 8. I do not answer people when they ring my doorbell & $A P$ & $5(33.3 \%)$ & | (6.7\%) & - & | (6.7\%) & $8(53.3 \%)$ & 15 \\
\hline 9. I do not answer the phone due to my way of talking & AP & $3(20 \%)$ & - & - & - & $12(80 \%)$ & 15 \\
\hline 10. My way of speaking requires a greater respiratory effort & AM & - & - & - & $4(26.7 \%)$ & | | (73.3\%) & 15 \\
\hline II. My way of speaking requires greater effort & $\mathrm{AP}$ & - & - & - & $4(26.7 \%)$ & II (73. & 15 \\
\hline 12. My way of speaking requires greater motivation & AP & I (6.7\%) & - & $3(20 \%)$ & $4(26.7 \%)$ & $7(46.7 \%)$ & 15 \\
\hline 13. Talk me pain & AM & $9(60 \%)$ & | (6.7\%) & | (6.7\%) & | (6.7\%) & & 15 \\
\hline 14. Talking causes me pain & AM & $4(26.7 \%)$ & - & $4(26.7 \%)$ & $3(20 \%)$ & & 14 \\
\hline 15. I have to make effort to talk & AM & $2(13.3 \%)$ & $3(20 \%)$ & | (6.7\%) & | (6.7\%) & $8(53$. & 15 \\
\hline 16. Some people have trouble in understanding me & RS & | (6.7\%) & I (6.7\%) & $2(13.3 \%)$ & $2(13.3 \%)$ & $9(60$ & 15 \\
\hline 17. Most of people have trouble in understanding me & RS & | (6.7\%) & - & - & $5(33.3 \%)$ & $9(60 \%)$ & 15 \\
\hline 18. It seems that people are bothered with my way of talking & RS & $5(33.3 \%)$ & $2(13.3 \%)$ & $3(20 \%)$ & $2(13.3 \%)$ & & 15 \\
\hline 19. My way of speaking embarrasses me & $\mathrm{AP}$ & $5(33.3 \%)$ & - & $3(20 \%)$ & $2(13.3 \%)$ & & 13 \\
\hline 20. I get annoyed when people ask me to repeat what I said & $\mathrm{AP}$ & $7(46.7 \%)$ & I (6.7\%) & $2(13.3 \%)$ & $3(20 \%)$ & & 15 \\
\hline 21. My speech is the same after surgery & AM & $12(80 \%)$ & | (6.7\%) & - & - & $2(13.7$ & 15 \\
\hline 22. I have difficulty in speaking some words & AM & I (6.7\%) & I (6.7\%) & - & $3(20 \%)$ & $10(66.7 \%)$ & 15 \\
\hline 23. I can be understood in a telephone conversation & RS & $9(60 \%)$ & $3(20 \%)$ & - & $3(20 \%)$ & - & 15 \\
\hline 24. Only my familyFamily can understand me & RF & $3(20 \%)$ & $2(13.3 \%)$ & $2(13.3 \%)$ & $4(26.7 \%)$ & $4(26.7 \%)$ & 15 \\
\hline $\begin{array}{l}\text { 25. Only one person in the family understands me and she } \\
\text { always helps me to explain my speech to the others }\end{array}$ & RF & $5(33.3 \%)$ & - & $3(20 \%)$ & $4(26.7 \%)$ & $3(20 \%)$ & 15 \\
\hline $\begin{array}{l}\text { 26. There are some people in my family that do not talk to } \\
\text { me because they do not understand my speech }\end{array}$ & $\mathrm{RF}$ & $2(13.3 \%)$ & - & $2(13.3 \%)$ & $2(13.3 \%)$ & & 15 \\
\hline 27. My family has no patience with me because of my speech & RF & $9(60 \%)$ & - & - & $3(20 \%)$ & $3(20 \%)$ & 15 \\
\hline $\begin{array}{l}\text { 28. People finish the conversation with me when they do not } \\
\text { understand what I say }\end{array}$ & RS & $4(26.7 \%)$ & - & $4(26.7 \%)$ & I (6.7\%) & & 15 \\
\hline 29. People pretend that they understood what I said & $A P$ & & I (6.7\%) & $3(20 \%)$ & $3(30 \%)$ & $7(46.7 \%)$ & 15 \\
\hline 30. Only my friends can understand me & RS & $9(60 \%)$ & - & $3(20 \%)$ & $2(13.3 \%)$ & I (6.7\%) & 15 \\
\hline $\begin{array}{l}\text { 31. I need someone to explain (translate) my speech because } \\
\text { other people do not understand me }\end{array}$ & AP & $3(20 \%)$ & - & & | (6.7\%) & & 15 \\
\hline 32. I cannot be understood by anyone & AP & $10(66.7 \%)$ & I (6.7\%) & $3(20 \%)$ & - & | (6.7\%) & 15 \\
\hline 33. I cannot be understood by anyone so I use the writing & EU & $6(40 \%)$ & $3(20 \%)$ & - & $3(20 \%)$ & $3(20 \%)$ & 15 \\
\hline 34. My speech is always understood & $\mathrm{AP}$ & I (6.7\%) & $5(33.3 \%)$ & $6(40 \%)$ & $2(13.3 \%)$ & | (6.7\%) & 15 \\
\hline $\begin{array}{l}\text { 35. My speech most of the time is comprehensive, there is a } \\
\text { need for repetition }\end{array}$ & AP & I (6.7\%) & - & $2(13.3 \%)$ & $7(46.7 \%)$ & $5(33.3 \%)$ & 15 \\
\hline $\begin{array}{l}\text { 36. My speech is usually understandable, but does not } \\
\text { require theface to face contact }\end{array}$ & AP & $8(53.3 \%)$ & I (6.7\%) & $3(20 \%)$ & (1) & $3(20 \%)$ & 15 \\
\hline $\begin{array}{l}\text { 37. My speech is usually understandable, but it is not necessary } \\
\text { to write some words for people to fully understand me }\end{array}$ & AM & $6(40 \%)$ & - & $3(20 \%)$ & $5(33.3 \%)$ & I (6.7\%) & 15 \\
\hline 38. My speech is difficult to be understood & $\mathrm{AP}$ & $2(13.3 \%)$ & - & $3(20 \%)$ & $3(20 \%)$ & $7(46.7 \%)$ & 15 \\
\hline 39. I get annoyed when people do not understand my speech & AP & $4(26.7 \%)$ & - & $6(40 \%)$ & $2(13.3 \%)$ & $3(20 \%)$ & 15 \\
\hline $\begin{array}{l}\text { 40. My speech is never understood, I have to use written } \\
\text { communication }\end{array}$ & AM & $9(60 \%)$ & I (6.7\%) & $2(13.3 \%)$ & I (6.7\%) & $2(13.3 \%)$ & 15 \\
\hline 4I. I find it difficult to produce certain types of sounds & AM & I (6.7\%) & - & | (6.7\%) & $3(20 \%)$ & $10(66.7 \%)$ & 15 \\
\hline
\end{tabular}


Cont. Table I. Functional assessment of communication with patients after total laryngectomy. Adapted from Bertoncello (2004)

\begin{tabular}{|c|c|c|c|c|c|c|c|}
\hline Issues & $\begin{array}{l}\text { Commu- } \\
\text { nication } \\
\text { domains }\end{array}$ & $\begin{array}{l}\text { Notat } \\
\text { all true } \\
\text { score } \\
\mathrm{n}(\%)\end{array}$ & $\begin{array}{c}\text { Somewhat } \\
\text { true } \\
\text { score } \\
\mathrm{n}(\%)\end{array}$ & $\begin{array}{l}\text { More } \\
\text { true } \\
\text { score } \\
\mathrm{n}(\%)\end{array}$ & $\begin{array}{c}\text { Very } \\
\text { true } \\
\text { score } \\
\mathrm{n}(\%)\end{array}$ & $\begin{array}{c}\text { Very much } \\
\text { true } \\
\text { score } \\
\mathrm{n}(\%)\end{array}$ & Total \\
\hline 42. I can sing & AM & $10(66.7 \%)$ & $2(13.3 \%)$ & - & $2(13.3 \%)$ & I (6.7\%) & 15 \\
\hline 43. I can change my tone of voice & AM & $9(60 \%)$ & $3(20 \%)$ & - & $2(13.3 \%)$ & I (6.7\%) & 15 \\
\hline 44. I am able to hold long conversations with people & AP & $4(26.7 \%)$ & $3(20 \%)$ & $2(13.3 \%)$ & | (6.7\%) & $5(33.3 \%)$ & 15 \\
\hline 45. I find it difficult to maintain long conversations with people & AP & $5(33.3 \%)$ & I (6.7\%) & - & $4(26.7 \%)$ & $5(33.3 \%)$ & 15 \\
\hline 46. My communication got worse after surgery & AP & $2(13.3 \%)$ & - & I (6.7\%) & $3(20 \%)$ & $9(60 \%)$ & 15 \\
\hline 47. My communication improved after surgery & AP & $9(60 \%)$ & $3(20 \%)$ & - & $2(13.3 \%)$ & I (6.7\%) & 15 \\
\hline $\begin{array}{l}\text { 48. After surgery I stopped expressing my ideas because of } \\
\text { the difficulty of talking }\end{array}$ & AM & $2(13.3 \%)$ & - & I (6.7\%) & $3(20 \%)$ & $9(60 \%)$ & 15 \\
\hline 49. I can speak to family members on the phone & RF & $12(80 \%)$ & - & - & I (6.7\%) & $2(13.3 \%)$ & 15 \\
\hline 50. I can talk to friends on the phone & RF & $12(80 \%)$ & - & I (6.7\%) & - & $2(13.3$ & 15 \\
\hline 5I. I can talk to strangers on the phone & RS & $12(80 \%)$ & I (6.7\%) & - & - & $2(13.3 \%)$ & 15 \\
\hline $\begin{array}{l}\text { 52. I can normally use my voice to communicate in social } \\
\text { situations }\end{array}$ & RS & $6(40 \%)$ & - & $2(13.3 \%)$ & I (6.7\%) & $6(40 \%)$ & 15 \\
\hline 53. I can normally use my voice to communicate at work & RS & NA & NA & $2(13.3 \%)$ & I (6.6\%) & NA & 3 \\
\hline 54. People realize that I speak differently & AP & - & - & - & I (6.7\%) & | $4(93.3 \%)$ & 15 \\
\hline 55. When I speak people look at me differently & AP & $3(20 \%)$ & - & $2(13.3 \%)$ & $2(13.3 \%)$ & $8(53.3 \%)$ & 15 \\
\hline
\end{tabular}

Evaluation of Communication Satisfaction of Patients after Total Laryngectomy adapted from Bertoncello (20) (Table 1). The adapted instrument for this study consists of fifty five 55 specific items for functional communication evaluation with highly satisfactory reliability indices. Has Each has 5 five possible answers: (1) not at all true, (2) somewhat true, (3) more true, (4) very true, and (5) very much true.

For analysis purposes, we chose to organize the 55 questions from the Bertoncello protocol (20) in five 5 communication domains (Table 2): (1) Family Relationship, (2) Social Relationship, (3) Staff Analysis, (4) Morphofunctional Appearance, and (5) Writing Use. The original numbering of the Protocol was maintained. The protocol used has the peculiarity to of providing responses that may indicate positive and negative characteristics traits from the five 5 possible answers. To optimize the responses, analysis in each domain was rated on positive and negative aspects.

All participants were treated in the SEFON of the hospital, a reference institution center for oncology treatment in the North and Northeast of Brazil. In SEFON, the patients receive speech therapy before and after surgery to and orientation and rehabilitation of chewing, deglutition, and voice functions. Fifteen individuals postwho underwent laryngectomy participated voluntarily at in this study., The study population included two 2 females women (13.3\%) and thirteen 13 males men (86.6\%), aged between 47 and 73 years with a mean age of 62.8 years. The collected surveys were performed from January to February 2011.

Considering the profile for research participants who were illiterate or poorly schooling, we chose to read the protocol by the researcher, where and the participant would only choose one answer for each question presented; giving also the patients the option of reading the protocol by themselves. To obtain more reliable answers produced by the participant, and considering that the public profile of the research presents difficulties in speech production due to laryngectomy, we designed a feature assistive technology: the Visual Response Scale. Depending on The Technical Assistance Committee, at the ATA's Seventh Meeting of the Committee on Technical Assistance, Special Secretariat for Human Rights (22) stated as follows:

Assistive technology is an area of knowledge, of interdisciplinary character, which includes products, resources, methodologies, strategies, practices, and services that aim to promote the functionality, related to the activity and participation of people with disabilities, incapacities or reduced mobility, seeking autonomy independence, quality of life and social inclusion. (BRAZIL, 2007).

The instrument contained in staggered columns with a single color (blue), where each column had a lighter tone subsequent number of responses related to the protocol. The participant indicates the desired response, 
Table 2. Functional assessment of communication in patients post-after total -laryngectomy. Adapted from Bertoncello (2004): positive and negative aspects.

\begin{tabular}{lll}
\hline CommunicationDomain & \multicolumn{2}{c}{ Matter Relating } \\
& PositiveAspect(+) & Negative Aspect(-) \\
\hline Family Relationship(RF) & 49,50 & $3,24,25,26,27$ \\
Social Relationship(RS) & $1,23,28,51--53$ & $2,4,5,16,17,18,30$, \\
SelfAnalysis(AP) & $34,35,36,47$ & $6,7,8,9,11,12,19,20,29,31,32,38,39,44,45,46,54$, \\
55 & $21,41,42,43$ & $10,13,14,15,22,48$ \\
Morphofunctionalaspects(AM) & 37 & 33,40 \\
Writing Use(UE) & &
\end{tabular}

Table 3. Profile of research of participants research.

\begin{tabular}{|c|c|c|c|c|c|c|c|c|c|}
\hline \multirow{2}{*}{ Name } & \multicolumn{2}{|c|}{ Gender } & \multirow{2}{*}{ Age } & \multicolumn{4}{|c|}{ Schooling } & \multicolumn{2}{|c|}{ Active } \\
\hline & Male & Female & & Illiterate & I to 4 years & 5 to 8 years & 9 to 11 years & & \\
\hline PACI & 1 & & 68 & & I & & & 1 & \\
\hline PAC2 & I & & 65 & I & & & & I & \\
\hline PAC 3 & I & & 57 & & I & & & & \\
\hline PAC 4 & | & & 61 & & I & & & & \\
\hline PAC 5 & | & & 56 & I & & & & & \\
\hline PAC 6 & | & & 86 & & I & & & & \\
\hline PAC 7 & | & & 58 & & I & & & I & \\
\hline PAC 8 & | & & 70 & & I & & & & \\
\hline PAC9 & I & & 63 & & I & & & & \\
\hline PAC 10 & 1 & & 70 & & I & & & & \\
\hline PAC II & I & & 57 & & & I & & & \\
\hline PAC 12 & & I & 58 & & I & & & & \\
\hline PAC 13 & I & & 47 & I & & & & & \\
\hline PAC 14 & & I & 57 & & I & & & & \\
\hline PAC 15 & I & & 73 & & I & & & & \\
\hline $\begin{array}{l}\text { TOTAL } \\
\text { (\%) }\end{array}$ & $\begin{array}{c}13 \\
(86,7)\end{array}$ & $\begin{array}{c}2 \\
(13,3)\end{array}$ & $62,8^{*}$ & $\begin{array}{c}3 \\
(20 \%)\end{array}$ & $\begin{array}{c}11 \\
(73,3 \%)\end{array}$ & $\begin{array}{c}\text { I } \\
(6,7 \%)\end{array}$ & 0 & $\begin{array}{c}3 \\
(20 \%)\end{array}$ & $\begin{array}{c}12 \\
(80 \%)\end{array}$ \\
\hline
\end{tabular}

OBS: *These data refer to the mean age of participants.

relating the column size and color depth to the order of their responses. Please note that appeal was presented to the participant, however, used only with the concurrence of the same. All caregivers were instructed to wait for the response of the participant, allowing the subject patient himself to answer autonomously themselves.

The average time of the protocol application was forty 40 minutes. The analysis was performed using descriptive statistics, using a simple frequency and average due to the qualitative profile of the study.

\section{RESULTS}

The scenario presented in building the profile of participants can be seen in Table 3, relating gender, age, schooling, and job function. Contains the following data among the participants, $86.7 \%$ are were male and $13.3 \%$ were female, with a mean age of 62.8 years. There is was prevalence of low schooling, totaling (93.3\%), considering the illiterate subjects and from those with 1 to 4 years of schooling. Of the respondents, 3 (20\%) are in were working activity and 12 (80\%) are were retired.

Of the possible 825 events, 798 were recorded. The questions no. 2 and no. 53 were related to the work, thus twelve participants did not answer. One participant did not answer the question no. 14, and two non answered question no. 19.

The responses collected from the fifteen 15 participants are were organized from three perspectives (Table 4): (a) the five types of responses (Not at all true, Little True, More True, Very True, and Very Much True), (b) the Communication Domain (Family Relationship, Social 
Table 4. Results of the answers as to Communication Domain in its positive and negative aspects.

\begin{tabular}{|c|c|c|c|c|c|c|c|c|c|c|c|}
\hline \multirow[t]{2}{*}{ Communication Domain } & \multicolumn{2}{|c|}{ NPV } & \multicolumn{2}{|c|}{ PV } & \multicolumn{2}{|c|}{$M N$} & \multicolumn{2}{|c|}{ BV } & \multicolumn{2}{|c|}{ MTV } & \multirow[t]{2}{*}{ Total } \\
\hline & + & - & + & - & + & - & + & - & + & - & \\
\hline Family Relationship & 24 & 22 & 3 & 3 & I & 10 & I & 16 & 4 & 24 & 105 \\
\hline Social Relationship & 29 & 29 & 7 & 3 & 5 & 19 & 6 & 17 & 16 & 40 & $17 \mid$ \\
\hline SelfAnalysise & 19 & 70 & 9 & 10 & | | & 34 & | | & 36 & 10 & 118 & 328 \\
\hline Morphofunctional aspect & 31 & 19 & 6 & 5 & & 8 & 4 & 18 & 4 & 54 & 149 \\
\hline Writing use & 6 & 15 & & 4 & 3 & 2 & 5 & 4 & I & 5 & 45 \\
\hline Total & 109 & 155 & 22 & 25 & 20 & 73 & 27 & 91 & 35 & 241 & 798 \\
\hline
\end{tabular}

Subtitles: NPV, - not at all true; PV, - a little true; MV, - true; BV, - very true; MTV, - very much true. (+) Positive aspect, (") Negative aspect.

Table 5. General framework reflecting good and poor quality of life $(\mathrm{QOL})$ from the responses obtained in 705 instances of positive and negative aspects.

\begin{tabular}{lccccc}
\hline Communication Domain & \multicolumn{2}{c}{$\begin{array}{c}\text { Responses Thatreflect } \\
\text { Good Qv }\end{array}$} & \multicolumn{2}{c}{$\begin{array}{c}\text { Responses Thatreflect } \\
\text { Bad Poor Qv }\end{array}$} & Total \\
& occurrences \\
& (AN)NPV/PV & (AP)BV/MTV & (AP) NPV/PV & (AN)BV/MTV & \\
\hline Family Relationship & $25(25,8 \%)$ & $5(5,2 \%)$ & $27(27,8 \%)$ & $40(41,2 \%)$ & $97(100 \%)$ \\
Social Relationship & $32(21,7 \%)$ & $22(15 \%)$ & $36(24,5 \%)$ & $57(38,8 \%)$ & $147(100 \%)$ \\
SelfAnalysise & $80(28,3 \%)$ & $21(7,4 \%)$ & $28(9,9 \%)$ & $154(54,4)$ & $283(100 \%)$ \\
Morphofunctional aspect & $24(17 \%)$ & $8(5,7 \%)$ & $37(26,2 \%)$ & $72(51,1 \%)$ & $141(100 \%)$ \\
Writing use & $19(47,5 \%)$ & $6(15 \%)$ & $6(15 \%)$ & $9(22,5 \%)$ & $40(100 \%)$ \\
\hline Total & $180(25,4 \%)$ & $62(8,8 \%)$ & $134(18,9 \%)$ & $332(46,9 \%)$ & $708(100 \%)$ \\
\hline GeneralTotal & $242(34,2 \%)$ & $466(65,8 \%)$ & \\
\hline
\end{tabular}

Subtitles: QOL, - quality of life; AN, - negative aspect; AP, - positive aspect; NPV, - not at all true; PV, - a little true; BV, very true; MTV, - very much true.

Relationship, Personnel Analysis, Appearance Morphofunctional Appearance, and Writing Use), and (c) the positive and negative aspects of each domains.

The overall picture (Table 5) reflects the responses of participants considering which would point to a good communication quality of life and which would point to a poor quality of life in communication, from the number of occurrences in each of the Communication domains, categorizing them into two groups: the more negative responses, like, "not at all true " (NPV) and "somewhat true" (PV); and, the most positive, like, "very true" (BV) and "very much true" (MTV). Ninety-three responses such as "very much true" (MV) had a total of 93 occurrences and were discarded for this analysis to position themselves in a intermediary categorization proposed by the protocol Bertoncello (2004), aiming for greater objectivity. Thus, instances of the analysis are added to 705 responses were analyzed.

Of the 705 events (Table 5) present at the end of the protocol application adapted from Bertoncello (20), there were 97 cases for the Family Relationship domain, 147 to for the Social Relationship domain, 283 instances for the Personal Analysis item, 141 cases for the Appearance
Morphofunctional item, and 40 occurrences for the Writing Use Item.

The results of each items of Communication Domains in relation to responses that point to indicate a good quality of life in communication (BGQVC) and those that who suggest poor quality of life in communication (MPQVC) were as follows: Family relationship item: - BQVC GQVC, with 30 occurrences (31.9\%) and MQVC PQVC, with 64 occurrences (68.1\%); Social Relationship item: - BGQVC, with 54 occurrences (36.7\%) and MPQVC, with 93 occurrences (63.3\%); Staff Analysis item: - BGQVC, with 101 occurrences (35.7\%) and MPQVC, with 182 (64.3\%); Morphofunctional Appearance item: - BGQVC, with 32 occurrences (22.7\%) and MPQVC, with 109 (77.3\%); Writing Use Item: - BQVCGQVC, with 25 occurrences (62.5\%) and MQVCPQVC, with 15(37.5\%). Computed responses suggest show that our findings is of BQVCGQVC of have 242 occurrences (34.3\%) and those that suggest of MQVCPQVC, have 463 occurrences (65.7\%).

\section{DisCUSSION}

The protocol adopted (20) consists of direct questions 
and easily understood by participants; , however, we analyzed the need for greater autonomy in the production of responses by subjects. Although not shown, it is common to caregivers or companions of people after who have undergone total laryngectomy generally take for them the word of speak for the patients, by because of the own nature of the communication disorder.

In While analyzing the profiles of respondents (Table 3), even considering the relatively small sample size (fifteen 15 members), total laryngectomy there were was more frequent in males (86.7\%) than in females (13.3\%). This finding agrees with the literature on laryngeal cancer, which occurrs predominantly in males, as well as does the age of the study sample, which shows variation between 50 and 70 years (3,23-24). According to the INCA in 2012 (1), it is not recommended to estimate the cancer in women in 2012 is not recommended due to its low magnitude incidence.

The schooling of the sample was characterized as low (93.3\%), adding to consider the illiterate (20\%) and those who attended between 1 and 4 years of formal education (73.3\%). This is a common fact finding among low-income people in the Brazilian reality. Only one 1 participant reported having schooling between 5 and 8 years (6.7\%) and none between 9 and 11 years.

The profile of laryngectomized participants with a low schooling level of this research sample was also found in other studies $(20,25-26)$. Thus, the schooling of the participants could interfere in the production provision of answers as this type of activity, because these participants are not familiar with the questionnaire is not very familiar in their daily lives. However, a questionnaires answered by the patients themselves as is a resource commonly used tool for assessing the quality of life (24).

When we proposed the use of an assistive technology with the Visual Response Scale was used, we observed that this instrument helped to safety in facilitated the responses of participants who opted for it.

Sometimes, the verbal response was associated with the use of the instrument, reflecting the need to of the respondent's to ensure understanding of by the evaluator, since it was someone outside of their immediate communication. This behavior suggests the uncertainty of the respondents in the use of verbal communication in new situations, on the part of respondents.

However, it should not fail to consider the artificiality of communication involved in the use of a questionnaire implementation of as an instrument of evaluation should also be considered. Even if the evaluator seeks to perform the activity with the greatest possible comfort for the participant, the circumstances of impartiality can not be disregarded. Importantly, to point out that all volunteers have demonstrated desire and devotion in the active participation of in the research.

Of the three subjects patients who that met the functional occupancy (20\%), all are were male and are aged between 58 and 68 years. The total number of retirees consisteds of twelve subjects participants (80\%) with aged between 47 and 73 years; seven men and two women (60\%) have had a lower age for retirement, age being a total of $60 \%$. Thus, it is anticipated since the time of retirement is due to the onset of cancer. Of respondents who were working, all claimed that their voice can could be understood, even partially, in question 53 .

In the discussion in relation to regarding gender, the two women in the study have had undergone schooling between 1 and 4 years, are were retired, and their responses indicated greater impairment in communication, corroborating the findings by Gomes (17).

For developing a closer look, the Table 5 shows the occurrences on the Communications domains organized into two groups for the two responses that the said dispute, or type responses Not at all true (NPV) and little true (PV) and two 2 more to confirm the saying, and they very true (BV) and very much true (MTV). The intermediate response More True (MV) was discarded to had provide balance in relation to nature of the responses. With this table, we seek to sharpen the look at more clearly outline the relationship that formed between the quality of responses and their relationship to the quality of life of this research population.

Writing use is presented as an alternative communication method, used but not necessarily desired, as soon as there is the implication of failure case of verbal communication failed. In question 37 , which talks about discussed not using writing as a means to make himself oneself understood, a balanced was a result of the response was obtained, where with six subjects said they disagreeing, six agreeing, with said and three opting for an intermediate response, More True (MV). These results, an apparently positive writing use item, reflected in $62.5 \%$, still must be balanced, taking into account the low schooling level, so either do not make use of writing, or they use it of restricted mode.

The Family Relationship item was the second of more negative (69\%) item, after the morphofunctional aspect item (77.3\%), according to protocol data. Patients may have had some difficulties while answering issues related to the Family Relationship item may have had 
some degree of difficulty to be answered, since family members often play the role of accompanying the patient. Still, the high rate of responses that indicate difficulties of family interaction can be illustrated by the question 03 , which states that the respondent's way of speaking interferes with family relationships; where eight subjects (53.3\%) confirmed the said with the two more affirmative responses and three did so with an intermediate responses, totaling eleven replies indicating full or partial agreement (73.3\%). This is a group composed consisted of $80 \%$ of retirees, so the family life becomes more intense and in view of the participants, the communication aspect is strongly marked in a negative way.

Although the profile of the study population to provided users of esophageal speech, Bertoncello (2004, p.86) describes research, as in Carr et al [2000], where the subjects, even varying the type of oral rehabilitation, present commitments in relation to quality of life in communication.

The morphofunctional aspect stands out for its highest incidence in relation to others. Some data that follow illustrate and may serve as a tipping point for both the speech therapist, as and for related areas. It can be seen that $66.7 \%$ of patients responded positively to the items of discomfort and greater effort (question 15 and 16); . Although not being the majority, $33.3 \%$ of patients had pain when speaking, because it and this could be controlled. There was a greater negative impact on all questions relating to the act of singing (question $42,-80 \%$ ), change the in voice tone (question 43, to 86.6\%), and send producing some speech sounds (question 22, - 80\%). Faced with this panorama this wide variety of conditions, it may be possible to suggest treated by multidisciplinary interventions that will minimize it.

Talking on the phone was characterized as an indicative outline of the difficulties presented in the communication interaction of people post-who had undergone laryngectomyzed, with family, friends, or strangers ( $80 \%$ of respondents as ""very true" "for each group). In Brazil, more than fixed telephony, mobile telephony is more prevalent than fixed telephon Brazil is among the technologies available today, getting to have with more lines of cell phone lines, than the number of people in over twenty Brazilian states (27). While talking on the phone is an activity common to most of the Brazilians, for patients post-who have undergone laryngectomy people this activity involves great difficulty practice presents itself as an element of great disorder.

Regarding the Social Relationship domain, the question 17 portrays the negative impact on dealing with the others, where fourteen (93.3\%, adding to MTV and BV) of respondents said that most people have difficulty in understanding them.

In this study, the following limits can be highlighted as relevant to communication quality of life in patients surviving after laryngectomy survival: great difficulty in verbal interaction with family, friends, and strangers; friends move away become distant; the phone is a feature that worsens the communicative situation; annoyance when it is not understood; physical discomfort when speaking; and finally, failure to express their ideas.

For people who have left are able still to express their ideas, participation in this study may had have represented a listening moment. Professionals and families to reflect on this data, can show how they are emotional and social interaction committed, and the urgency of changes in a difficult reality experienced by this group. Perhaps, the participation of post-laryngectomy patients has provided its own subject reflection on condition to a right of communication.

\section{CONCLUSION}

The adapted Protocol Assessment of Communication Satisfaction of Patients after Total Laryngectomy (21) was relevant to the objective of this research objectives, allowing it to have providing an overview of the communication quality of life of those who have undergone went total laryngectomy and presenting, as a consequence, changes in your previous standards of communicative functioning. The Visual Response Scale, such provided as assistive technology, proved to be a facilitator, contributing to an inclusive stance against the persons subjected to undergoing total laryngectomy.

The role of speech therapy interventions pervades these areas of speech communication. From Among the techniques used, all have favorable and unfavorable aspects. Taking into account various factors, however, none of them allowed a satisfactory level of excellence. It will consider wish the individual, since there is need to develop new learning and skills to be involved by the same, which require flexibility and adaptation, and they can not always reach them (28).

Concernabout the quality of life refers to a movement in the human and biological sciences in appreciating broader parameters that controls symptoms, decreased mortality, and increased life expectancy (25). Quality of life can be a very subjective concept, but subjectivity can not be an impediment to be for enhanced techniques, since this could lead to stagnation of this type of research $(28,29)$. 
Language permeates all these domains that make constitute the quality of life, and through it the human relations are established through language (26). After laryngectomy, Where once there was a guy person with fluent and independent discourse, is to present a scenario of experience linguistic isolation and silence; imposed on himself in the person also faces of negative attitudes, subjective or explicit, their from social peers. Social relations from a non-standard communication results in changes in the behavior of some patients. The norm centrism imposed by the different models of truth, implies paradigms breaking in the context of their own health professionals. Therefore, the stigma of normality reported by Larrosa and Skliar (30) expelled discursive spaces of various groups, among them laryngectomyzed people.

Knowledge with more properly the questions about of these changes that bring them in produce social limitations, could be a force arm the people submitted to individuals who have undergone total laryngectomy, compared to deal with managers of public politics, allowing more focused on promoting health communication actions.

The expansion of this sector of studies favors the demystification of a non-standard human communication, from a multiprophessional intervention, promoting rehabilitation, recovery, or even resetting establishment of new goals near to this for post-laryngectomyzed, with quality of life.

\section{THANKS}

To REBRANTS/CNPq, the Electromyography Laboratory of the Graduate Program in Pathology, UFPE, and the Cancer Hospital of Pernambuco.

\section{REFERENCES}

1. Instituto Nacional de Câncer José Alencar Gomes da Silva (INCA)/Ministério da Saúde (MS). Estimativa 2012: incidência de câncer no Brasil- Rio de Janeiro: Inca, 2011.

2. Hannickel S, Zago MMF, Barbeira CBS, Sawada NO. O comportamento dos laringectomizados frente à imagem corporal. Rev Bras de Cancerol. 2002;48(3):333-39.

3. Silva LSL, Pinto MH, Zago MMF. Assistência de enfermagem ao laringectomizado no período pós-operatório. Rev Bras de Cancerol. 2002;48(2):213-11.

4. Freitas TA, Lynch CS, Silva HMM. Câncer de laringe e fonoaudiologia. Rev Lato \& Sensu, Belém. 2003;4(1):35 .
5. Furia CLB. Reabilitação fonoaudiológica nas ressecções de boca e faringe. In: Carrara de Angelis E, Furia CLB, Mourão LF, Kowalski LP. A atuação fonoaudiológica no câncer de cabeça e pescoço. São Paulo: Lovise, 2000. p. 209-19

6. Amar A, Rapoport A, Franzi AS, Bisordi C, Lehn CN. Qualidade de vida e prognóstico nos carcinomas epidermóides de cabeça e pescoço. Rev Bras de Otorrinolaringol. 2002;68(3):parte 1.

7. Katz MR, Irish JC, Devins GM, Rodin GM, Gullane PJ. Psychosocial adjustment in head and neck cancer: the impact of disfigurement, gender and social support. Head and Neck, Feb. 2003.

8. Miller EH, Quinn AI. Dental considerations in the management of head and neck cancer patients. Otolaryngol Clin North Am. 2006;39(2):319-29.

9. Sawada NO, Dias AM, Zago MMF. O efeito da radioterapia sobre a qualidade de vida dos pacientes com câncer de cabeça e pescoço. Rev Bras de Cancerol. 2006;52(4):32329 .

10. Mozzini CB, Schuster RC, Mozzini AR. O esvaziamento cervical e o papel da fisioterapia na sua reabilitação. Rev Bras de Cancerol. 2007;53(1):55-61.

11. Salomão CHD, Melo AS, Carvalho EC. Incertezas do paciente a ser submetido à cirurgia de laringectomia total. Rev Enferm UFPE. 2008;2(1):55-60.

12. Barrichello E. Distúrbios no padrão do sono em pacientes submetidos à cirurgia oncológica. São Paulo, 2008, p. 114 (Tese de Doutorado - Escola de Enfermagem de Ribeirão Preto. Universidade de São Paulo).

13. Biazevic MG, Antunes JL, Togni J, Carvalho MB. Immediate impact of a primary surgery on health-related quality of life of hospitalized patients with oral and oropharyngeal cancer. J. Oral Maxilofac. Surg. 2008;66(7):1343-50.

14. Barros BPA, Angelis CE, Lourenço CTM et al. Qualidade de vida, depressão e hipertireoidismo após laringectomia total. Rev Bras Cir Cabeça Pescoço. 2006;35(1):26-31.

15. Barros BPA, Portas, GJ Queija SD. Implicações da traqueostomia na comunicação e na deglutição. Rev Bras Cir Cabeça Pescoço. 2009;8(3):202-207.

16. Akduman D, Karaman M, Uslu C et al. Larynnx câncer treatment results: survive and quality of life assessment. Kulak Burun Boagaz Ihtis Derg. 2010;20(1):25-32. 
17. Gomes TABF, Rodrigues FM. Qualidade de vida do laringectomizado traqueostomizado. Rev Bras Cir de Cabeça e Pescoço. 2010;39(3):199-205.

18. Paula FC, Gama RR. Avaliação de qualidade de vida em laringectomizados totais. Rev Bras Cir de Cabeça e Pescoço. 2009;38(3):177-182.

19. Fleck MPA. Versão em português dos instrumentos de avaliação de qualidade de vida (WHOQOL) 1998 - Divisão de Saúde Mental Grupo WHOQOL-OMS. Psiquiatria. UFRGS. Disponível em: <http://www.ufrgs.br/psiq/whoqol1. html\#top> Acesso em: 24 nov. 2009

20. Bertoncello KCG. Qualidade de Vida e a Satisfação da Comunicação do Comunicação do Paciente após a Laringectomia Total: construção e validação de um instrumento de medida. São Paulo, 2004, p. 226 (Tese de Doutorado - Escola de Enfermagem Geral de Ribeirão Preto/ USP).

21. Brasil. Conselho Nacional de Educação/ Ministério da Educação. Resolução № 1, de 14 de janeiro de 2010 .

22. Brasil. Comitê de Ajudas Técnicas, na ATA da VII Reunião do Comitê de Ajudas Técnicas, da Coordenadoria Nacional Para Integração Da Pessoa Portadora De Deficiência, Secretaria Especial dos Direitos Humanos. Brasília. 13 e 14 de 2007.

23. Wunsgh VF. The epidemiology of laryngeal cancer in Brazil. São Paulo Medical Journal. 2004;122(5):188-94.

24. Maciel CTV, Leite ICG, Soares TV. Câncer de laringe: um olhar sobre a qualidade de vida. Revista Interdisciplinar de
Estudos Experimentais - Animais e Humanos (RIEE). 2010;2(4):126-134.

25. Moreno AB, Lopes CS. Avaliação da qualidade de vida em pacientes laringectomizados: uma revisão sistemática. Caderno de Saúde Pública, Rio de Janeiro. 2002;18(1):8192.

26. Carmo RD, Camargo Z, Nemr K. Relação entre qualidade de vida e auto-percepção da qualidade vocal de pacientes laringectomizados totais: estudo piloto. Rev CEFAC, São Paulo. 2006;8(4):518-28.

27. Brasil. Em 20 estados e no DF há mais telefones celulares do que habitantes. Disponível em: <http:// www.brasil.gov.br/noticias/arquivos/2011/10/19/em-20estados-e-no-df-ha-mais-telefones-celulares-do-quehabitantes> Acesso em: 26/01/2012.

28. Gonçalvez, MI, Behlau, MS. Laringectomia Total: perspectivas de reabilitação vocal. In: Lopes Filho, OC. Tratado de Fonoaudiologia. São Paulo: Roca, 1997, p.10651077.

29. Oliveira IB, Costa CC, Chagas JFS, Rochetti ECG, Oliveira LO. Comunicação oral de laringectomizados com prótese traqueoesofágica: análise comparativa pré e pós-treino. PróFono Revista de Atualização Científica, Barueri (SP). 2005;17(2):165-174.

30. Larrosa J, Skliar C (Eds.). Habitantes de Babel: políticas e poéticas da diferença. Belo Horizonte: Autêntica Editora, 2001. 